\title{
Nutrient reduction in rations with phytase for growing pigs ${ }^{1}$
}

\author{
Valéria Vânia Rodrigues ${ }^{2}$, Vinícius de Souza Cantarelli ${ }^{3}$, Nikolas de Oliveira Amaral $^{3}$, Márcio \\ Gilberto Zangeronimo ${ }^{4}$, Jeronimo Ávito Gonçalves de Brito ${ }^{5}$, Elias Tadeu Fialho ${ }^{3}$
}

\footnotetext{
1 Projeto financiado pela FAPEMIG.

2 Departamento de Zootecnia/Universidade Federal de Viçosa - UFV.

${ }^{3}$ Departamento de Zootecnia/Universidade Federal de Lavras - UFLA.

${ }^{4}$ Departamento de Medicina Veterinária/Universidade Federal de Lavras - UFLA.

5 Pesquisa e Desenvolvimento/Indústria UNIQUÍMICA Ltda São Paulo - SP.
}

\begin{abstract}
Two experiments were conducted to evaluate the performance, the energy and nutrient balance and economic viability of production of growing pigs fed diets with reduced levels and phytase. In experiment 1, 60 barrows and gilts (initial weight $25 \pm 1.72 \mathrm{~kg}$ ) were housed in a randomized block design with three diets, ten replicates and two animals per experimental unit (one male and one female). One of the diets was formulated with a reduced level with phytase and evaluated in comparison to a positive-control diet that was formulated according to the nutritional recommendations for animals of this breed, and a negative-control diet without phytase. The different diets did not affect feed intake, but the diet with phytase promoted better final weight, daily weight gain and feed conversion, although it did not differ from the positive control diet. In experiment 2, 27 barrows (initial weight $49 \pm 3.67 \mathrm{~kg}$ ) were housed in random blocks with three diets and nine replicates with experimental plot represented by one animal. The diets did not affect the balance of energy and nutrients but had a significant effect on the efficiency of utilization of calcium and phosphorus, which was the lowest in animals that received the positive-control diet. Economic viability improved when nutrients were reduced and phytase was added in the ration. The addition of phytase $(500 \mathrm{ftu} / \mathrm{kg})$ in rations formulated with nutritional levels reduced for growing swines improves rearing productivity and it is economical viable.
\end{abstract}

Key Words: diet formulation, enzyme, metabolism, nutrition, performance

\section{Redução de nutrientes em rações com fitase para suínos em crescimento}

RESUMO - Dois experimentos foram conduzidos para avaliar o desempenho, o balanço de energia e nutrientes e a viabilidade econômica da produção de suínos em crescimento alimentados com rações com níveis reduzidos e fitase. No experimento 1, 60 suínos machos castrados e fêmeas (peso inicial de $25 \pm 1,72 \mathrm{~kg}$ ) foram alojados em delineamento de blocos casualizados, com três dietas, dez repetições e dois animais por unidade experimental (macho e fêmea). Uma das dietas foi formulada com nível reduzido e com fitase e avaliada em comparação a uma dieta controle positivo, formulada conforme as recomendações nutricionais para animais da linhagem, e a uma dieta controle negativo, sem fitase. As dietas não influenciaram o consumo de ração, porém aquela com fitase promoveu melhor peso final, ganho de peso diário e conversão alimentar, embora não tenha diferido da controle positivo. No experimento 2, 27 suínos machos castrados (peso inicial de $49 \pm$ 3,67 kg) foram alojados em blocos ao acaso com três dietas e nove repetições com parcela experimental representada por um animal. As dietas não afetaram o balanço de energia e nutrientes, mas tiveram efeito significativo na eficiência de utilização de cálcio e fósforo, que foi pior nos animais que receberam a dieta controle positivo. A viabilidade econômica melhorou com a redução de nutrientes e adição de fitase na ração. A suplementação de fitase (500 ftu/kg) em rações formuladas com níveis nutricionais reduzidos para suínos em crescimento melhora a produtividade da criação, além de ser economicamente viável.

Palavras-chave: desempenho, enzima, formulação de ração, metabolismo, nutrição

\section{Introduction}

The search for greater productivity in the swine industry has led to changes in nutritional plans for diet formulation, reflecting both the performance of the animal and the financial return to the producer. Current research studies focus on improving the efficiency of feed utilization by aligning the availability of nutrients in diet formulations with the nutritional requirements of animals.

Phosphorus $(\mathrm{P})$ is the second most common mineral nutrient required by swines and the third most costly in diets for these animals (Silva et al., 2008). In foods of plant 
origin, this mineral is present in the form of phytic acid, which has low availability to monogastric animals because these animals do not naturally have sufficient phytase in the gastrointestinal tract. As a result, P-use efficiency is low for plant-derived foods (Jongbloed et al., 1992).

One possible solution to improve nutrient utilization in diets for pigs is the use of phytase as a feed additive. In addition to increasing the phosphorus availability, phytase increases the digestibility of energy and other minerals and amino acids, enabling lower nutrient levels to be used in diet formulation (Zanella et al., 1999). Therefore, diets containing low levels of protein, energy and minerals but supplemented with phytase have improved the same animal performance as diets containing higher nutrient levels.

The development of specific nutritional plans based on the species, diet composition and physiological stage of a particular animal can significantly improve profitability (Shelton et al., 2004). Such plans reflect the real composition of the ingredients available to the animal, thus reducing the cost of formulation and yielding more consistent performance.

In this study, animal performace, nutrient balance and economic viability of diets for growing pigs with different levels of nutrients and energy and with or without phytase supplementation were evaluated.

\section{Material and Methods}

Two experiments were carried out in the Departamento de Zootecnia of Universidade Federal de Lavras, Lavras, southern Minas Gerais. In the performance trial (Experiment 1), 30 barrows and 30 gilts with an average initial weight of $25 \pm 1.7 \mathrm{~kg}$ and an average final weight of $50 \pm 2.9 \mathrm{~kg}$ were distributed in a randomized-block design with three diets, ten replicates and two animals per experimental unit (one male and one female). The criterion used to form blocks was the weight of the animals. The animals were housed in pairs in a shed divided into stalls with concrete floors $(2.3 \times 1.5 \mathrm{~m})$, equipped with semi-automatic feeders and water troughs, during the 30-day experimental period.

The experimental diets (Table 1) were composed of corn and soybean meal supplemented with vitamins, minerals and amino acids. The positive-control diet was formulated to meet the nutritional recommendations for the breed of the animal. The other two diets were formulated to test the nutritional plan under study; one was supplemented with phytase (500 ftu/kg diet; obtained from the fermentation of transgenic Saccharomyces cerevisiae containing genes from the gram-negative bacteria Escherichia coli and Citrobacter braakii), whereas the other did not contain phytase. These two diets contained $0.36 \%$ crude protein,

Table 1 - Composition of the experimental diets

\begin{tabular}{|c|c|c|c|}
\hline \multirow[t]{2}{*}{ Ingredient } & \multirow[t]{2}{*}{ Positive control } & \multicolumn{2}{|c|}{ Nutritional reduction } \\
\hline & & Without phytase & With phytase \\
\hline Corn & 68.23 & 71.0 & 71.0 \\
\hline Soybean meal & 27.2 & 25.9 & 25.9 \\
\hline Soybean oil & 1.35 & 0.31 & 0.31 \\
\hline Dicalcium phosphate & 1.40 & 0.68 & 0.68 \\
\hline Limestone & 0.740 & 0.883 & 0.883 \\
\hline Salt & 0.300 & 0.300 & 0.300 \\
\hline Vitamin-mineral mix ${ }^{1}$ & 0.400 & 0.400 & 0.400 \\
\hline L-lysine $\mathrm{HCl}$ 78\% & 0.240 & 0.253 & 0.253 \\
\hline DL-methionine $99 \%$ & 0.070 & 0.062 & 0.062 \\
\hline L-threonine $98 \%$ & 0.050 & 0.047 & 0.047 \\
\hline Phytase $^{2}$ & 0.0 & 0.0 & 0.005 \\
\hline Growth promoter ${ }^{3}$ & 0.02 & 0.02 & 0.02 \\
\hline Kaolin & 0.0 & 0.145 & 0.14 \\
\hline \multicolumn{4}{|l|}{ Calculated composition } \\
\hline Metabolizable energy (kcal/kg) & 3255 & 3220 & 3220 \\
\hline Crude protein (\%) & 17.99 & 17.63 & 17.63 \\
\hline Available phosphorus (\%) & 0.356 & 0.226 & 0.226 \\
\hline Calcium (\%) & 0.706 & 0.586 & 0.586 \\
\hline Digestible lyisine (\%) & 1.005 & 0.990 & 0.988 \\
\hline Digestible methionine (\%) & 0.333 & 0.321 & 0.321 \\
\hline Digestible threonine (\%) & 0.649 & 0.633 & 0.633 \\
\hline Digestible tryptophan (\%) & 0.191 & 0.185 & 0.185 \\
\hline
\end{tabular}

${ }^{1}$ Composition/kg Product: cobalt - $125 \mathrm{mg}$, copper - 5,000 mg, iron - 17,500 mg; iodine - $200 \mathrm{mg}$; Mn - 10,000 mg; selenium - $125 \mathrm{mg}$, zinc - 20,000 mg; niacin 6,250 mg; folic acid - $150 \mathrm{mg}$; pantothenic acid - 2,500 mg; Biotin - $12.5 \mathrm{mg}$; hill - 60,000 mg; vit. A - 2,000,000 U.I.; vit. B1 - 250 mg; vit. B12 - 5,000 mcg; vit. B2 - 1,000 mg; vit. B6 - 500 mg; vit. C - 12500 mg; vit. D3 - 300,000 U.I.; vit. E - 5000 IU; vit. K3 - 625 mg; BHT - 500 mg.

2 Enzymatic additive with phytase activity (Genophos - $500 \mathrm{ftu} / \mathrm{kg}$ of diet).

${ }^{3}$ Active ingredient - Tylosin granulated. 
$35 \mathrm{kcal} / \mathrm{kg}$ gross energy, $0.13 \%$ phosphorus, $0.12 \%$ calcium, $0.017 \%$ digestible lysine, $0.007 \%$ digestible methionine, $0.014 \%$ digestible methionine + cystine, $0.016 \%$ digestible threonine, $0.003 \%$ digestible tryptophan and $0.014 \%$ digestible valine.

Diets and water were given ad libitum to the animals. The stalls were cleaned daily, and the feed and wastes were weighed twice a day to determine feed consumption of each pair of animals. To measure weight gain, each animal was weighed at the beginning and at the end of the experiment, and the feed-conversion ratio was calculated from the relationship between feed intake and weight gain during the experimental period.

In the metabolism trial (experiment 2), 27 barrows with an average initial weight of $49 \pm 3.7 \mathrm{~kg}$ were housed individually in metabolic cages (one animal per experimental unit), as described by Sales et al. (2003), allowing feces and urine to be collected separately. The cages were stored in an air-conditioned room, allowing partial control of the internal temperature at around $22 \pm 2.4^{\circ} \mathrm{C}$.

Because there were not enough metabolic cages available for all animals, the experiment consisted of three consecutive periods of nine days each. The experimental design consisted of randomized blocks with three diets and nine replicates (three replicates in each period). Each experimental unit was represented by a single animal, and the three diets were the same as the ones used in the performance test. During each period, the animals were given a five-day period to adapt to the cages, and total feces and urine were collected for four days.

The animals were weighed at the beginning and at the end of each period. Feed were given at 8 a.m. and 4 p.m., and the total daily amount was established based on the body metabolic weight $\left(\mathrm{BW}^{0.75}\right)$. The amount of feed was adjusted to the consumption of the animal with the lowest intake observed during the adjustment period so all animals would consume equal amounts of nutrients in relation to their metabolic weight. Ferric oxide $\left(\mathrm{Fe}_{2} \mathrm{O}_{3}\right)$ was used as a marker for fecal material, and feces were collected every morning and afternoon, packed in plastic bags and stored in a freezer $\left(-20^{\circ} \mathrm{C}\right)$. Later, the fecal samples were stored at room temperature until they had thawed and then they were weighed and mixed. An approximately 600 -g sample from each collection was oven-dried $\left(65^{\circ} \mathrm{C}\right)$ and exposed to air for an hour to balance moisture content at room temperature. The dried sample was weighed again to determine its original moisture content. After weighing, the sample was milled and packaged in glass for laboratory analysis. Similarly, urine was collected daily using a plastic bucket with a filter. The bucket contained $20 \mathrm{ml}$ of hydrochloric acid (HCl) 1:1 to prevent bacterial growth and a possible nitrogen loss. Distilled water was added to the total urine collected from each animal to standardize the volume collected. From this total daily sample, $10 \%$ of the standardized volume was removed and frozen $\left(-20^{\circ} \mathrm{C}\right)$ for further analysis.

Gross energy content was determined by combustion in a PARR model 2081 adiabatic bomb calorimeter (AOAC, 1995). From the results of laboratory analyses of the diets and excreta, it was calculated the coefficients of dry-matter digestibility, apparent digestibility of energy, gross digestible energy and metabolizable energy.

The Kjeldahl method was used to determine the nitrogen content in the feed, feces and urine, according to AOAC (1990), and dry-matter content (except for urine) and total nitrogen were calculated using the methods of Silva \& Queiroz (2002) to determine the amounts of nitrogen absorbed and retained by the animal.

Calcium and phosphorus levels in the feces and diets were analyzed by using acid digestion with nitric and perchloric acid (1:2). After that, they were filtered to obtain a mineral solution. Phosphorus and calcium readings were obtained by using colorimetry and atomic absorption, respectively, according to AOAC (1990), for later determination of calcium and phosphorus balance. All tests were performed at the Laboratório de Pesquisa Animal at UFLA.

To analyze the economic feasibility of phytase supplementation in low-nutrient diets for growing pigs, total cost was calculated as described by Cantarelli et al. (2009).

Data were submitted to analysis of variance using the statistical package SISVAR (System for Analysis of Variance for Balanced Data), developed by Ferreira (2000). To compare different treatments and to interpret the results, Scott-Knott test at the 5\% significance level was used.

\section{Results and Discussion}

Phytase supplementation had no effect $(\mathrm{P}>0.05)$ on the feed intake of the animal (Table 2). This result was expected because the energy composition of the diet did not differ much (35 kcal) between the positive-control diet and the low-nutrient diets. According to Kerr et al. (2003), differences in energy content of less than about $124 \mathrm{kcal}$ are too small to influence feed intake.

These results are consistent with those obtained by Figueiredo et al. (2000), who also observed no significant effect of phytase supplementation on feed intake for growing pigs. Moreover, Veum et al. (2006) compared swine diets containing adequate levels of phosphorus and no phytase 
Table 2 - Performance of pigs from 25 to $50 \mathrm{~kg}$ fed diets with or without phytase ${ }^{1}$

\begin{tabular}{lcccr}
\hline Variable & Positive control & \multicolumn{2}{c}{ Nutritional reduce } & \multicolumn{2}{c}{ Average } \\
\cline { 3 - 4 } & & Without phytase & With & phytase \\
\hline Final weight (kg) & $50.95 \mathrm{a}$ & $48.35 \mathrm{~b}$ & $50.14 \mathrm{a}$ & 49.82 \\
Average daily feed intake (kg/day) & 1.95 & 1.93 & 1.99 & 3.20 \\
Average daily weight gain (kg/day) & $0.84 \mathrm{a}$ & $0.76 \mathrm{~b}$ & $0.82 \mathrm{a}$ & 0.96 \\
Feed conversion & $2.32 \mathrm{~b}$ & $2.58 \mathrm{a}$ & $2.43 \mathrm{~b}$ & 6.27 \\
\hline
\end{tabular}

${ }^{1}$ Means followed by different letters in the row differ $(\mathrm{P}<0.05)$ by Scott-Knott test.

(positive control) to diets that were $0.15 \%$ deficient in phosphorus and supplemented with various levels of phytase or without phytase (negative control). Those authors observed that the feed intake of the animals increased at the highest levels of phytase supplementation compared to the positive control.

Phytase supplementation significantly affected $(\mathrm{P}<0.05)$ body weight and daily weight gain. The reduced-nutrient diet supplemented with phytase promoted the best animal performance but did not differ significantly from the positivecontrol diet. These results are consistent with those obtained by Lei et al. (1993), who also found positive effects of phytase supplementation on the weight gain of growing pigs. Many other studies have shown positive effects of phytase on the performance of pigs (Kies et al., 2006; Veum et al., 2006). According to Choct (2006), the presence of phytase in the diet can increase phosphorus availability in foods by $70 \%$.

The results for weight gain indicate that phytase supplementation in low-nutrient diets is effective in addressing the nutritional requirements of pigs through increased availability of organic phosphorus in the diet. Animals fed such a diet did not differ from those fed diets with the recommended nutrient levels.

Phytase also influenced $(\mathrm{P}<0.05)$ feed conversion, improving the performance of animals fed the low-nutrient diet, but with no significant difference from the positivecontrol diet. This improvement is probably related to the increase in daily weight gain because feed consumption was not affected.
These results are consistent with those obtained by Brana et al. (2006), who evaluated pig diets containing adequate levels of phosphorus (positive control) and phosphorus-deficient diets with or without (negative control) phytase supplementation. Those authors observed better feed efficiency in pigs fed diets supplemented with phytase. This enzyme appears to be effective in phosphorusdeficient diets due to its efficiency in hydrolyzing phytate in feed, providing greater amounts of phosphorus to the animal with a consequent performance improvement.

Thus, the addition of phytase to pig diets can be a viable solution to improve animal performance (Costa et al., 2007). Moreover, the use of phytase in commercial diets with low nutrient levels may be economically viable because it permits the reduction of nutrient levels in the diet formulation, which reduces costs while maintaining animal performance.

Although performance was increased by the addition of phytase, there was no effect $(\mathrm{P}>0.05)$ on variables related to energy balance and nitrogen for the same amount of digestible dry matter. However, regarding the efficiency of phosphorus utilization, phytase supplementation improved $(\mathrm{P}<0.05)$ the absorption and retention of the mineral, and the diet containing phytase yielded values similar to those of the negative-control group and higher than those of the positive-control group for calcium utilization (Table 3 ).

According to Liao et al. (2005), the presence of phytate may lead to the formation of phytate-starch complexes, reducing the digestibility of dietary energy, and may inhibit

Table 3 - Energy digestibility and nutrient balance of diets for growing pigs fed diets with or without fitase ${ }^{1}$

\begin{tabular}{|c|c|c|c|c|c|}
\hline \multirow[t]{2}{*}{ Variable } & \multirow[t]{2}{*}{ Positive control } & \multicolumn{2}{|c|}{ Nutritional reduce } & \multirow[t]{2}{*}{ Mean } & \multirow[t]{2}{*}{ CV $(\%)$} \\
\hline & & Without phytase & With phytase & & \\
\hline Digestible dry matter (\%) & 87.55 & 87.95 & 88.01 & 88.04 & 1.66 \\
\hline Digestible energy $(\mathrm{kcal} / \mathrm{kg})^{2}$ & 3356 & 3348 & 3330 & 3345 & 1.83 \\
\hline Metabolizable energy $(\mathrm{kcal} / \mathrm{kg})^{2}$ & 3112 & 3103 & 3061 & 3092 & 3.55 \\
\hline Nitrogen absorbed (\%) & 86.29 & 87.08 & 86.44 & 86.61 & 2.13 \\
\hline Calcium balance (\%) & $54.99 b$ & $63.17 \mathrm{a}$ & $65.58 \mathrm{a}$ & 61.24 & 6.03 \\
\hline Phosphorus balance (\%) & $45.10 \mathrm{~b}$ & $46.39 \mathrm{~b}$ & $52.29 \mathrm{a}$ & 47.93 & 10.29 \\
\hline
\end{tabular}

${ }^{1}$ Means followed by different letters in the row differ $(\mathrm{P}<0.05)$ by Scott-Knott test.

${ }^{2}$ Values expressed in natural matter. 
$\alpha$-amylase, an important enzyme that participates in the process of carbohydrate digestion. In the present study, the associations between phytic acid and starch may not have been sufficient to influence the digestibility of energy through increased enzyme activity. Furthermore, the similarity between the effects of the diet supplemented with phytase and those of the positive-control diet can be explained by the fact that the difference in dietary energy was too small to influence the energy digestibility.

Similar results have been found by Walz \& Pallauf (2002), who provided diets supplemented with phytase to growing pigs and found no variation in the digestibility of dry matter, digestible energy and metabolizable energy. Likewise, O’Quinn et al. (1997) obtained similar results for energy-related variables. Furthermore, Ketaren et al. (1993) studied material removed from the ileum of growing pigs and found greater energy retention with phytase supplementation in the diet.

In a review, Mroz et al. (1994) proposed that the improved digestibility of phytase-supplemented diets may be explained by the release of phytate-protein complexes from the starch present in soybean and corn meal. Namkung et al. (1999) also reported that responses to phytase supplementation may be influenced by the chemical and structural properties of phytate-protein complexes. In such complexes, several amino acids may be linked to the phytate molecule, forming insoluble complexes, thus decreasing the digestibility of the phosphorus for the animal.

These results are consistent with those observed by Ruiz et al. (2008), who also found no differences in nitrogen uptake in piglets fed diets composed of corn, soybean and rice bran supplemented or not with phytase (500 ftu/kg diet).

Different results have been reported by Walz \& Pallauf (2002), who observed an increase of $16 \%$ in nitrogen retention in pigs fed low-nutrient diets with or without phytase supplementation. Likewise, Bruce \& Sundst (1995) have reported that phytase influences nitrogen retention in pigs.

According to Qian et al. (1996), phytase supplementation in swine diets should occur when the molar ratio of cations (calcium and phosphorus) is as low as possible, close to 1.2:1. When this ratio is above $2: 1$ or $3: 1$, insoluble complexes may be formed, impairing nutrient absorption by the animal.

Oberle \& Harland (1996) have explained that because phytate binds to the basic amino acids in protein molecules, these amino acids will not be released if they are bound into complexes that are more resistant to the action of phytase. This enzyme acts by releasing phytic acid and, by extension, any amino acid linked to the complex.
In a review, Nunes (1998) observed that if adequate amounts of calcium and phosphorus are supplied to the animal, the utilization of these nutrients will be more efficient if they are supplied in the appropriate proportion. Therefore, further research is necessary to determine the extent to which calcium and phosphorus in the diet can influence nutrient digestibility and affect the performance of pigs.

According to Viana et al. (2009), phytic acid in plant-derived foods is less available to monogastric animals because there is little or no phytase activity in their gastrointestinal tracts. Research on phytase supplementation consistently shows beneficial effects, especially on phosphorus availability. The results of the present study reinforce this consensus. Similar results were obtained by Veum et al. (2006) and Hill et al. (2009), who found that phosphorus, calcium and magnesium availability were the greatest in phytase-supplemented low-nutrient diets for pigs.

Nortey et al. (2007) have also analyzed nutrient digestibility in phytase-supplemented diets for growing pigs and observed greater absorption and retention of calcium and phosphorus when the enzyme was present in the feed. However, in the present study, phytase did not show a strong effect on calcium utilization by growing pigs. The diets (except the positive control) probably exhibited higher calcium availability because they were formulated with low levels of the mineral, leading to better utilization by the animal. The negative-control and phytasesupplemented diets contained $17 \%$ less calcium compared to the positive-control diet.

According to Murray et al. (1990), the absorption of calcium into the bloodstream of the animal and its utilization by the cells is regulated primarily by three hormones responsible for balancing the plasma concentrations of the mineral: parathyroid hormone, calcitonin and estrogen. Parathyroid hormone stimulates the movement of calcium and phosphate from the bones to the blood, especially when there is a deficiency of minerals in the diet.

However, different results were found by Sands et al. (2001), who observed greater calcium retention in growing pigs fed diets containing phytase than in those fed normal corn-based diets.

The presence of phytase in the diet increases nutrient availability and can improve animal performance, However, a range of results were obtained, which may be related to variation among the microbial strains used for commercial production of phytase and to variation in dosage, in addition to the formation of complexes between phytate and other dietary ingredients. 
The control diet had a total cost significantly $(\mathrm{P}<0.05)$ high (Table 4). This result suggests that diet formulations that follow the recommended nutrient levels will impose greater costs due to the larger amounts of nutrients needed in the diet compared to formulations with reduced nutrient levels and phytase supplementation.

Feed costs contribute up to $70 \%$ of the total production cost for swine (Nunes et al., 2001). Therefore, results shown in this study provide a viable alternative feeding plan for swine producers. Diets formulated with low nutrient levels but without supplemental phytase cost even less $(\mathrm{P}<0.05)$, but such diets cannot be recommended because they will decrease the animal performance.

Similar results were obtained by Fireman et al. (2000), who found that lower feed costs per kilogram of body weight of the pig were possible by using phytase in the diet. However, Santos et al. (2008) found no economic viability for phytase supplementation in a study using the enzyme in association with reduced inorganic-phosphorus content in the diet. These results are related to the cost of ingredients used to improve animal performance and the cost of the enzyme.

Table 4 - Economic feasibility of the use of rations formulated with or without fitase for pigs from 25 to $50 \mathrm{~kg}^{1}$

\begin{tabular}{lccccc}
\hline Variable & Positive control & \multicolumn{3}{c}{ Nutritional reduce } & \multicolumn{3}{c}{ Mean } \\
\cline { 3 - 5 } & & Without phytase & With phytase \\
\hline Total cost $(\mathrm{R} \$)$ & $92.36 \mathrm{a}$ & $88.9 \mathrm{~b}$ & $89.8 \mathrm{~b}$ & 90.36 \\
\hline
\end{tabular}

${ }^{1}$ Means followed by different letters in the row differ $(\mathrm{P}<0.05)$ by Scott-Knott test.

\section{Conclusions}

The addition of phytase ( $500 \mathrm{ftu} / \mathrm{kg}$ ) to diets for growing pigs formulated with reduced nutrient levels is economically viable and increases productivity.

\section{Acknowledgment}

The authors gratefully acknowledge Fundação de Amparo à Pesquisa do Estado de Minas Gerais (FAPEMIG) and also Pesquisa \& Desenvolvimento - Indústria UNIQUIMICA Ltda for their financial support for this project.

\section{References}

ASSOCIATION OF OFFICIAL ANALYTICAL CHEMIST - AOAC. Official methods of analysis. 15.ed. Arlington, 1990. 1230p. ASSOCIATION OF OFFICIAL ANALYTICAL CHEMIST - AOAC. Official methods of analysis. 16.ed. Washington, D.C., 1995. v.1. cap.16.

BRANA, D.V.; ELLIS, M.; CASTANEDA, E.O. et al. Effect of a novel phytase on growth performance, bone ash and mineral digestibility in nursery and grower-finisher pigs. Journal of Animal Science, v.84, n.4, p.1839-1849, 2006.

BRUCE, J.A.M.; SUNDST, F. The effect of microbial phytase in diets for pigs on apparent ileal and faecal digestibility, $\mathrm{pH}$ and flow of digesta measurements in growing pigs fed a high-fibre diet. Journal of Animal Science, v.75, n.1, p.121-127, 1995.

CANTARELLI, V.S.; FIALHO, E.T.; ALMEIDA, E.C. et al. Características de carcaça e viabilidade econômica do uso de cloridrato de ractopamina para suínos em terminação com alimentação à vontade ou restrita. Ciência Rural, v.39, n.3, p.844-851, 2009.

CHOCT, M. Enzymes for the feed industry: past, present and future. Word's Poultry Science Journal, v.62, n.1, p.5-15, 2006.
COSTA, F.G.P.; BRANDÃO, P.A.; BRANDÃO, J.S. et al. Efeito da enzima fitase nas rações de frangos de corte, durante as fases pré-inicial e inicial. Ciência e Agrotecnologia, v.31, n.3, p.865-870, 2007.

FERREIRA, D.F. Análises estatísticas por meio do Sisvar para Windows versão 4. 0. In: REUNIÃO ANUAL DA REGIÃO BRASILEIRA DA SOCIEDADE INTERNACIONAL DE BiOMETRIA, 45., 2000, São Carlos. Anais... São Carlos: Universidade Federal de São Carlos, 2000. p.255-258.

FIGUEIREDO, A.V.; FIALHO, E.T.; VITTI, D.M.S.S. et al. Ação da fitase sobre a disponibilidade biológica do fósforo, por intermédio da técnica de diluição isotópica, em dietas com farelo de arroz integral para suínos. Revista Brasileira de Zootecnia, v.29, n.1, p.177-182, 2000.

FIREMAN, F.A.T.; LÓPEZ, J.; FIREMAN, A.K.B.T. Desempenho e custos de suínos alimentados com dietas contendo 50\% de farelo de arroz integral suplementados com fitase e/ou celulase. Archive Latinoam Production Animal, v.1, n.8, p.18-23, 2000.

HILL, B.E.; SUTTON, A.L.; RICHERT, B.T. Effects of low-phytic acid corn, low-phytic acid soybean meal, and phytase on nutrient digestibility and excretion in growing pigs. Journal of Animal Science, v.87, n.4, p.1518-1527, 2009.

JONGBLOED, A.W.; MROZ, Z.; KEMME. A. The effect of supplementary Aspergillus niger phytase in diets for pigs on concentration and apparent digestibility of dry matter, total phosphorous, and phytic acid in different sections of the alimentary tract. Journal of Animal Science, v.701, p.159-1168, 1992.

KERR, B.J.; YEN, B.J.; NIENABER, J.A. et al. Influences of dietary protein level, amino acid supplementation and environmental temperature on performance, body composition, organ weights and total heat production of growing pigs. Journal of Animal Science, v.81, n.8, p.1998-2007, 2003.

KETAREN, P.P.; BATTERHAM, E.S.; DETTMANN, E.B. et al. Phosphorus studies in pigs. 3. Effect of phytase suplentation on the digestibility and availability of phosphorus in soya-bean meal for grower pigs. Bristish Journal of Nutrition, v.70, n.1, p.289-311, 1993.

KIES, A.K.; KEMME, P.A.; SEBEK, L.B.J. et al. Effect of graded doses and a high dose of microbial phytase on the digestibility of various minerals in weaner pigs. Journal of Animal Science, v.84, n.3, p.1169-1175, 2006. 
LEI, X.G.; KU, P.K.; MILLER E.R. et al. Supplementing cornsoybean meal diets with microbial phytase linearly improves phytate phosphorus utilization by weanling pigs. Journal of Animal Science, v.71, n.12, p.3359- 3367, 1993.

LIAO, S.F.; SAUER, W.C.; KIES, A.K. et al. Effect of phytase supplementation to diets for weanling pigs on the digestibilities of crude protein, amino acids and energy. Journal of Animal Science, v.83, n.3, p.625-633, 2005.

MROZ, Z.; JONGBLOED, A.W.; KEMME, P.A. Apparent digestibility and retention of nutrients bound to phytate complexes as influenced by microbial phytase and feeding regimen in pigs. Journal of Animal Science, v.72, n.1, p.126-132, 1994.

MURRAY, A.C.; LEWIS, R.D.; AMOS, H.E. The effect of microbial phytase in a pearl millet-soybean meal diet on apparent digestibility and retention of nutrients, serum mineral concentration and bone mineral density of nursery pigs. Journal of Animal Science, v.75, n.5, p.1284-1291, 1997.

MURRAY, R.K.; GRANER, D.K.; MAYNES, P.A. et al. Bioquímica. São Paulo: Atheneu, 1990. 705p.

NAMKUNG, H.; LEESON, S. The effect of phytase enzyme on dietary nitrogen-corrected apparent metabolizable energy and the ileal digestibility of nitrogen and amino acids in broiler chicks. Poultry Science, v.78, n.9, p.1317-1319, 1999.

NORTEY, T.N.; PATIENCE, J.F.; SIMMINS, P.H. et al. Effects of individual or combined xylanase and phytase supplementation on energy, amino acid, and phosphorus digestibility and growth performance of grower pigs fed wheat-based diets containing wheat millrun. Journal of Animal Science, v.85, n.6, p.1432-1443, 2007.

NUNES, J. I. Nutrição animal básica. 2.ed. rev. e aum. Belo Horizonte: FEP/MVZ, 1998. 387p.

NUNES, R.C.; KRONKA, R.N.; SALES, C.P. et al. Retirada dos suplementos micromineral e/ou vitamínico da ração de suínos em fase de terminação: características de carcaça e vida de prateleira da carne suína. Ciência Animal Brasileira, v.2, n.2, p.79-86, 2001.

OBERLAS, D.; HARLAND, B.F. Impact of phytate on nutrient availability. In: COELHO, M.B.; KORNEGAY, E.T. (Coords.). Phytase in animal nutrition and waste management. Mount Olive: BASF Corporation, 1996. p.77-84.

O’QUINN, P.R.; KNABE, D.A.; GREZ, E.J. Efficacy of Natuphos in sorghum-based diets of finishing swine. Journal of Animal Science, v.75, n.5, p.1299-1307, 1997.

QUIAN, H.; KORNEGAY, E.T.; CONNER JÚNIOR, D.E. Adverse effects of wide calcium : phosphorus ratios on supplemental phytase. Efficacy for wealing pigs fed two dietary phosphorus levels. Journal of Animal Science, v.74, n.6, p.1288-1297, 1996.

RUIZ, U.S.; THOMAZ, M.C.; HANNAS, M.I. et al. Complexo enzimático para suínos: digestão, metabolismo, desempenho e impacto ambiental. Revista Brasileira de Zootecnia, v.37, n.3, p.458-468, 2008.

SALES, G.T.; FIALHO, E.T.; VOLPATO, C.T. Modificação nas gaiolas metabólicas para experimentos com suínos. In: CONGRESSO DE INICIAÇÃO CIENTÍFICA DA ESCOLA SUPERIOR DE AGRICULTURA DE LAVRAS, 26., 2003, Lavras. Anais... Lavras: Universidade Federal de Lavras, 2003. p.249.

SANDS, J.S.; RAGLAND, D.; BAXTER, C. et al. Phosphorus bioavailability, growth performance, and nutrient balance in pigs fed high available phosphorus corn and phytase. Journal of Animal Science, v.79, n.8, p.2134-2142, 2001.

SANTOS, S.P.; NUNES, R.C.; LOPES, E.L. et al. Retirada do suplemento micromineral-vitamínico, redução de fósforo inorganico e adição de fitase em rações de suínos na fase de terminação. Ciência Animal Brasileira, v.9, n.3, p.663-671, 2008.

SHELTON, J.L.; SOUTHERN, L.L.; GASTON, L.A. et al. Evaluation of the nutrient matrix values for phytase in broilers. Journal of Applied Poultry Research, v.13, n.2, p.213-221, 2004.

SILVA, D.J.; QUEIROZ, A.C. Análises de alimentos: métodos químicos e biológicos. Viçosa, MG: Universidade Federal de Viçosa, 2002. 235p.

SILVA, J.H.V.; ARAUJO, J.S.; GOULART, C.C. et al. A. Influência da interação fósforo disponível $\times$ fitase da dieta sobre o desempenho, os níveis plasmáticos de fósforo e os parâmetros ósseos de poedeiras comerciais. Revista Brasileira de Zootecnia, v.37, n.12, p.2157-2165, 2008.

VEUM, T.L.; BOLLINGER, D.W.; BUFF, C.E. et al. A genetically engineered escherichia coli phytase improves nutrient utilization, growth performance and bone strength of young swine fed diets deficient in available phosphorus. Journal of Animal Science, v.84, n.5, p.1147-1158, 2006.

VIANA, M.T.S.; ALBINO, L.F.T.; ROSTAGNO, H.S. et al. Efeito da suplementação de enzima fitase sobre o metabolismo de nutrientes e o desempenho de poedeiras. Revista Brasileira de Zootecnia, v.38, n.6, p.1074-1080, 2009.

ZANELLA, I.; SAKOMURA, N.K.; SILVERSIDES, F.G. et al. Effect of enzyme supplementation of broiler diets based on corn and soybeans. Poultry Science, v.78, n.4, p.561-568, 1999.

WALZ, J.; PALLAUF, M. Microbial phytase combined with amino acid supplementation reduces $\mathrm{P}$ and $\mathrm{N}$ excretion of growing and finishing pigs without less of performance. International Journal of Food Science and Technology, v.37, n.7, p.835-848, 2002. 